\title{
Poor Weight Gain
}

National Cancer Institute

\section{Source}

National Cancer Institute. Poor Weight Gain. NCI Thesaurus. Code C111659.

Slower than normal rate of weight increase. 